\title{
ІНСТИТУЦЙНА ТА ЕКОНОМІЧНА ДИНАМІКА НАЦІОНАЛЬНОГО БІЗНЕСУ
}

\begin{abstract}
Цілями роботи є: генетико-алгоритмічний аналіз джерел дисфункції інституціональної основи бізнесової та економічної системи України; описання бар'єрів розвитку ефективного бізнесу та конкурениії; аналіз детермінант розбалансування механізмів розширеного відтворення капіталів 6 Україні. Авторами досліджено зміни компонент формальної та неформальної частин інституційного середовища. Виявлено, що загалом бар'єрами економічного росту є $і$ неефективна організація праці, особливо на держаних підприємствах, і неефективне використання людського капіталу, $і$ відсутність реальної реструктуризації капіталу, і відсутність інституту конкуренції.
\end{abstract}

Ключові слова: формальні інститути, неформальні інститути, інновації, конкуренція, приватизація, національна економіка.

Постановка проблеми. В умовах глобалізації світ вступає в нову реальність, яка вимагає від нього жити за принципами “глобального он-лайну". В результаті такого тотального впливу глобалізації змінюється специфіка розвитку світу, трансформаційномодернізаційних змін зазнають традиційні форми соціальної організації, на зміну яким приходить глобальне суспільство та суспільство глобального ризику [1]. За таких обставин виникають ризики, що відстаючі країни, можуть зникнути з геополітичної карти, перетворюючись у провінції чи фрагменти інших держав. Незважаючи на декларовану «відкритість» суспільства та прозорість економічних та політичних кордонів, які формує та вимагає глобалізація, Україна потрапила в трансформаційну економічну пастку. Вихід із трансформаційної пастки можливий тільки за рахунок зростання обсягу та якості національного бізнесу, який буде поступово все більш здатним формувати механізми економічної динаміки. Тому надзвичайно актуальною темою дослідження $\epsilon$ динаміка параметрів та факторів національного бізнесу в комплексному інституціональноекономічному просторі.

Аналіз останніх досліджень i публікацій. В роботах Вальраса, Робінсон, Кейнса, Хікса, Хансена, Самуельсона розроблено питання джерел економічної динаміки та механізмів формування поточної «приблизної» рівноваги. Серед українських вчених аналізу еволюції та функціо-

(C) Черленяк Іван Іванович, д.н. 3 держ.упр., проф., завідувач кафедри бізнес-адміністрування, маркетингу та менеджменту ДВНЗ «Ужгородський національний університет», тел.: +380993019642, e-mail: ivan.cherlenjak@uzhnu.edu.ua

Машіко К.С., к.е.н, старший науковий співробітник Закарпатського регіонального центру соціальноекономічних і гуманітарних досліджень НАН України моб.:+380509802741, e-mail: ekaterinna333@gmail.com нування моделей соціально-економічного розвитку України присвячені праці А. С. Гальчинського, В. М. Гейця, С.В. Мочерного, Ю. М. Пахомова, В. Р. Сіденко, О. І. Соскіна, Н. А. Татаренко, В. П. Череваня, А.А. Чухно. Ці роботи дали багато цінного для розуміння змісту економічних змін в Україні. Однак, перенесення концептів та логіки економічних моделей неокласичної теорії на проблематику української економіки сьогодні малорезультативне.

В роботах розробників неоінституціональної теорії розглянуто проблематику оптимального масштабу функціонування та впливу економічних агентів. Концепція автопоезиса суспільних комунікацій [3] демонструє яким чином соціальне середовище, інституціалізуючи певні процеси, сприяє самоорганізації економічних механізмів через циркуляцію релевантних дій та комунікацій по кібернетичному циклу «вхід - комунікацйно-трансформаційна матеріалізація - вихід». В нашому дослідженні ми залучаємо концепти неоіституціональної економічної теорії Д.Норта [2] та теорії автопоезису суспільних комунікацій Н.Луманна [3].

Третьою компонентою фундаменту нашого концептуального підходу стали узагальнення положень Я. Корнаї [4] та Г.Клейнера [5;6].

На основі синтезу змісту ідей трьох вищевказаних напрямків ми формулюємо тези необхідні для розуміння логіки подальшого тексту. 1) Соціально-економічна система та система національного господарства, що синхронно сумісно трансформуються від директивнопланового типу регулювання економіки до ринкового типу $є$ системою-процесом. 2) Це система-процес 3 високим рівнем складності за рахунок ендогенних факторів еволюціонування (саморуху). 3) В еволюційних суб'єктах типу система-процес кожна системно-структурна грань задає топологію та ієрархію зв'язностістійкості компонент та межі їх поведінки. 
4) Процесна грань задає умови-обставиничинники мінливості поведінки та ролей.

Формулювання цілей статті. Цілями роботи $€: 1)$ генетико-алгоритмічний аналіз джерел дисфункції інституціональної основи бізнесової та економічної системи України; 2) описання бар'єрів розвитку національного бізнесу та конкуренції; 3) аналіз детермінант розбалансування механізмів розширеного відтворення національного бізнесу в Україні.

Методологія дослідження Для розкриття сутності економічних відносин використовуємо причинно-наслідкові кроки (ряди) інституційних змін (структурно-генетичний підхід), а для розкриття механізмів росту-спаду підприємництва та обсягу капіталів: структурно-функціональний підхід. Для дослідження посткомуністичної трансформації та ідентифікації змісту системотворчих для трансформації явищ ми використовуємо діалектичний та тріалектичний методологічний інструментарій. Для дослідження акторної (ігрової) картини розвитку підприємництва, застосовуємо метод фактологічного аналізу даних, метод порівняльного аналізу експертноіндексних систем даних.

Формальні інститути були досліджені через призму нормативно-правових актів сфер приватної власності, приватизації, конкуренції, монополії, свободи підприємництва.

Для дослідження еволюції неформальних інститутів використано статистичні та аналітичні дані українських і міжнародних аналітичних та моніторингових організацій щодо стану інституційного середовища України, зокрема: щорічні доповіді Всесвітнього економічного форуму, Індекс сприйняття корупції 2014, Global Competitiveness Reports, The Worldwide Governance Indicators (WGI) Світового Банку, Звітиs «Doing Business», Рейтинг економічної свободи від Heritage Foundation, Nations in Transit Reports віл Freedom House, The Rule of Law Index від World Justice Project, Індекс трансформацій від The Bertelsmann Stiftung's.

Опис основного матеріалу дослідження. Створена у перше десятиліття незалежності інституційна структура приватизації повинна була б сприяти створенню в Україні багатоукладної ринкової економіки. Правда, ідеологи «ринкових трансформацій» забули наголосити, що природним чином ринок в індустріальну епоху виникає тільки коеволюційно iз розвинутим капіталістичним способом виробництва. Цей шлях в умовах нікчемно запровадженого інституту приватної власності привів до панування в економіці олігархії та створення ерзац-капіталізму в
Україні. Незважаючи навіть на те, що сьогодні в Україні існує юридично формально правильно означений інститут приватної власності тут планує бюджетно-роздатковий ерзац-капіталізм. Ми вважаємо, що тільки спряженість формальних та неформальних інститутів приватної власності та підприємництва 3 практикою бізнесу забезпечує ефективність сучасної капіталістичної системи. Для цього нами було здійснено аналіз даних сімох міжнародних рейтингів країн світу щодо соціального, політичного та економічного розвитку за період за період з 2006 по 20152016 роки. В результаті складові інституційного середовища були диференційовані за чотирма компонентами: правова система і законодавство; політика та державне управління; економічна сфера; суспільні трансформації. В залежності від змін значень індикаторів досліджуваних індексів та змін місця України в рейтингах, виділено 3 можливі варіанти змін інституційного середовища: позитивні та негативні зміни, відсутність змін (Табл. 1 ).

На основі аналізу експертних даних покомпонентно виведемо підсумок про динаміку ефективності-неефективності неформальних інститутів в фокусі ефективності національної економіки.

Правова система, законодавство. Відбулося покращення лише у сфері захисту основних прав (Fundamental rights). Решта складових зазнали погіршення стану. Особливо велике падіння відбулося у сфері «незалежності» судів: у Індексі глобальної конкурентоспроможності за цим показником Україна опустилася на 30 сходинок. Основне погіршення відбулося у період між 2008-2010 роками. Всі решта складових характеризуються несуттєвим погіршенням.

Політика та державне управління. Дані показують покращення багатьох важливих складових інституційного середовища. Позитивним є зростання суспільної довіри до політків, прозорість та краща координація в урядуванні. Найбільшого покращення зазнала міра регуляторного впливу держави, особливо після останніх революційних подій. Незважаючи на це, не вдалося подолати фаворитизму в урядових рішеннях, монополії кланів на використання ресурсів, покращити партійну системи. Зростання надійності публічних послуг намітилася лише у 2016 році. Майже в такій мірі, в якій знизилася обтяженість державним регулюванням, зросло марнотратство державних витрат. Різко впав рівень політичної стабільності. 
Динаміка змін в інституційному середовищі України у 2006-2015/2016 роках

\begin{tabular}{|c|c|c|}
\hline Позитивні & Негативні & Відсутність змін \\
\hline \multicolumn{3}{|c|}{ Правова система, законодавство } \\
\hline \multirow[t]{5}{*}{ Базові права } & Верховенство права & Об'єднання / право на збори \\
\hline & Якість регулювання & Кримінальне правосуддя \\
\hline & Судова незалежність & \\
\hline & Цивільні права, цивільне правосуддя & \\
\hline & Захист інтелектуальної власності & \\
\hline \multicolumn{3}{|c|}{ Політика та державне управління } \\
\hline $\begin{array}{l}\text { Довіра суспільства до } \\
\text { політиків }\end{array}$ & $\begin{array}{l}\text { Фаворитизм у рішеннях урядових } \\
\text { чиновників }\end{array}$ & $\begin{array}{l}\text { Місцеве демократичне } \\
\text { врядування }\end{array}$ \\
\hline $\begin{array}{l}\text { Тягар державного } \\
\text { регулювання }\end{array}$ & Національне демократичне управління & Розподіл владних повноважень \\
\hline $\begin{array}{l}\text { Основні адміністративні } \\
\text { структури }\end{array}$ & $\begin{array}{l}\text { Результативність демократичних } \\
\text { інститутів }\end{array}$ & \\
\hline Скоординованість політики & Державні видатки & \\
\hline \multirow[t]{5}{*}{ Відкрите урядування } & Монополія на застосування сили & \\
\hline & Надійність служб поліції & \\
\hline & Утвердження демократії & \\
\hline & Партійна система & \\
\hline & $\begin{array}{l}\text { Політична стабільність і відсутність } \\
\text { насильства }\end{array}$ & \\
\hline \multicolumn{3}{|c|}{ Економічна сфера } \\
\hline $\begin{array}{l}\text { Робота } 3 \text { дозволами на } \\
\text { будівництво }\end{array}$ & Сила стандартів аудиту і звітності & Рішення про неспроможність \\
\hline Започаткування бізнесу & Виконання контрактів & Приватне підприємство \\
\hline Реєстрація майна & Захист міноритарних інвесторів & \\
\hline \multicolumn{3}{|l|}{ Корпоративна етика } \\
\hline \multicolumn{3}{|c|}{ Суспільні трансформації } \\
\hline Свобода самовираження & Порядок і безпека & \\
\hline \multirow[t]{4}{*}{ Інтенсивність конфліктів } & Незалежні 3MI & \\
\hline & Традиції громадянського суспільства & \\
\hline & Організована злочинність & \\
\hline & Відсутність релігійного втручання & \\
\hline \multicolumn{3}{|c|}{ Компоненти, динаміка яких с спірною у різних індексах і рейтингах } \\
\hline \multirow[t]{2}{*}{$\begin{array}{l}\text { Права власності (The } \\
\text { Bertelsmann Stiftung's } \\
\text { Transformation Index) } \\
\end{array}$} & $\begin{array}{l}\text { Права власності (Economic freedom rank; } \\
\text { Індекс глобальної } \\
\text { конкурентоспроможності) }\end{array}$ & \\
\hline & $\begin{array}{l}\text { Виборчий процес (Nations in Transit } \\
\text { Ratings) }\end{array}$ & $\begin{array}{l}\text { Виборчий процес (The } \\
\text { Bertelsmann Stiftung's } \\
\text { Transformation Index) } \\
\end{array}$ \\
\hline \multirow{2}{*}{$\begin{array}{l}\text { Корупція (Global } \\
\text { Competitiveness index, Rule of } \\
\text { Law Index) }\end{array}$} & $\begin{array}{l}\text { Корупція (Economic freedom rank, Nations } \\
\text { in Transit Ratings) }\end{array}$ & \\
\hline & $\begin{array}{l}\text { Антикорупційна політика (Worldwide } \\
\text { Governance Indicators) }\end{array}$ & $\begin{array}{l}\text { Антикорупційна політика (The } \\
\text { Bertelsmann Stiftung's } \\
\text { Transformation Index) }\end{array}$ \\
\hline
\end{tabular}

\section{* Розроблено авторами на основі [7-25]}

Економічна сфера. Більшість інститутів економічної сфери характеризуються суттєвим покращенням. 32012 по 2016 роки за простотою реєстрації підприємств рейтинг України покращився на 82 сходинки (40 з яких у 2016 році). Згідно з даними Doing Business [18-20], у 2016 році для реєстрації підприємства в Україні треба пройти 4 процедури, це займе не більше семи днів. Вартість започаткування бізнесу $0,6 \%$ від доходу на душу населення. (Але реально це стосується тільки найпростішого бізнесу.) Для порівняння у 2009 році кількість процедур складала 10 , час - 27 днів, а вартість 5,5\% від доходу на душу населення.

Варто звернути увагу, що незважаючи на покращення корпоративної етики, забезпечення виконання зобов'язань за контрактами погіршилося особливо в проміжку між 2012 та 2015 роками. Без змін залишилася процедури врегулювання неплатоспроможності. Однак цей 
субіндекс у рейтингу «Doing Business» $[19 ; 20]$ для України $є$ найгіршим.

Суспільні трансформації. Суттєво знизилася інтенсивність суспільних, етичних і релігійних конфліктів. Дещо в меншій мірі підвищилася свобода вираження поглядів громадянами, організаціями i мас медіа. Водночас, незалежність засобів масової інформації стала більш сумнівною. Відбулося посилення впливу релігії на політичні інститути та правовий порядок. Особливо загрозливими у суспільстві суттєве зростання організованої злочинності та відсутність покращень у сфері порядку і безпеки.

3 таблиці 1 видно, що більше половини $(53,8 \%)$ інституційних змін мають негативні тенденції. Позитивних перетворень зазнали $30,8 \%$ складових компонентів інституційного середовища, відсутні зміни у $15,4 \%$ складових.

Також авторами виділено компоненти, динаміка яких є спірною у різних дослідженнях. До них відносимо захист прав власності, зміни у виборчому процесі, корупція та боротьба 3 нею. Стосовно виборчого процесу, то Bertelsmann Stiftung's Transformation Index [14] показав у 2006 та 2016 роках однакові показники. Однак за цей період відбулося падіння значень, які вдалося подолати лише у 2016 році. Тому вважаємо, що в цілому має місце позитивна динаміка вільних i чесних виборів. Але проблема, що пропозиція вибору партій вкрай обмежена та маніпулятивна.

3 корупцією ситуація подібна. Рейтинги, по яким в цілому було погіршення за період 20062016 роки, відобразили у 2015 і 2016 роки позитивну динаміку. Тому можемо зробити висновок, що на даний момент все ж таки $є$ позитивні зрушення у рівні корумпованості та боротьбі з нею.

Але неоднозначність оцінювання українських «капіталістичних» неформальних інститутів полягає насамперед у невідповідності змісту інститутів формі: сенс «євроатлантичної» економічної свідомості, на основі якої розроблені експертні рейтингові оцінювання не відповідають азійському феодальному (ординському) змісту економічної свідомості та економічної раціональності. Про це свідчить і те, що за результатами оцінювання «Національна система доброчесності Україна - 2015» [26] можна говорити про те, що корупція в України залишається системною проблемою на всіх рівнях державної влади. Рівень терпимості до корупції в українському суспільстві серйозно не зменшився 32005 року: оцінка сприйняття корупції у 2005 р. складала 2,6 бали, у 2007 р. 2,7 бали, у 2009 p. - 2,2 бали, у 2012 p. - 26 балів, у 2014 p. - 25 балів, у 2015 р. - 27 балів (оцінка за шкалою, де 0 балів - вкрай корумпована, 10 балів (100 балів після 2011 року) - дуже чиста від корупції ) [26].

Цілком у дусі апологетів «азійського феодалізму» майже третина українських громадян досі вважає, що корупція може бути виправдана, а хабар $\epsilon$ шляхом найменшого спротиву для розв'язання проблеми у відносинах 3 різними держустановами. Найкорумпованою сферою українці визнали судову $(66 \%)$, за нею слідують: правоохоронні органи (64\%), державна служба (56\%), сфера охорони здоров'я (54\%), парламент (53\%), політичні партії (45\%), освітня система (43\%), бізнес (36\%), військова сфера (28\%), 3МІ (22\%), релігійні інституції $(21 \%)$, громадські організації (20\%) [26].

У цілому з аналізованого індексу глобальної конкурентоспроможності інституційна складова $\epsilon$ найслабшою позицією України. Згідно Nations in Transit Ratings від Freedom House [11;12], Україна відноситься до перехідних урядів та гібридних режимів. Висновок The Bertelsmann Stiftung's (2017) свідчить, що в Україні існує дефективна демократія [14] , функціональні вади у ринковій економіці, і середній рівень дієвості управління.

Як бачимо, найбільшим бар'єром росту ефективності капіталів, а отже і росту економіки країни, стало те, що інститути капіталу, інститути капіталізму та інститути ринку концептуально i практично розірвані а не спряжені. Як замінник спряженими виявилися інститути влади-примусу та інститути влади грошей. Причому гроші корупційно неефективно спряжені із капіталом. При формуванні державнацій епохи органічного становлення капіталізму національна буржуазія була патріотична - вона фінансувала укріплення «політичної економіки» своєї держави. Українська космополітична буржуазія найчастіше антипатріотична - вона тримає фінансові багатства в офшорах, ухиляється від обов'язковим платежів на освіту, дороги, в цілому інфраструктуру, освіту, оборону.

Сукупність інституційних перетворень в Україні сформували соціально-економічну i політичну структуру яку називають «кумівським», «клановим», «олігархічним» капіталізмом. Однак постає питання, якими економічними рисами він характеризується і як ці риси проявляються у процесі розвитку країни. Природно очікувати, що капіталізм і ринкові умови господарювання через механізм конкуренції i необхідність ефективного функціонування повинні забезпечувати інноваційні процеси та зростання продуктивності праці. При цьому інноваційні розробки та нові 
знання як інструмент здатні в свою чергу підвищувати конкурентоспроможність країни на світових ринках, що було б важливо для України як країни, що розвивається. Але це не працює.
Для оцінки рівня інноваційності та порівняння інноваційних зусиль різних країн використано показник наукоємності ВВП або питомої ваги витрат на НДТР у ВВП країни.(Табл.2)

Таблиця 2

Питома вага витрат на виконання наукових досліджень та технічних розробок у ВВП деяких країн світу*

\begin{tabular}{|c|c|c|c|c|c|c|c|c|c|c|c|c|c|c|c|}
\hline Країна & 2000 & 2001 & 2002 & 2003 & 2004 & 2005 & 2006 & 2007 & 2008 & 2009 & 2010 & 2011 & 2012 & 2013 & 2014 \\
\hline Корея & 2,18 & 2,34 & 2,27 & 2,35 & 2,53 & 2,63 & 2,83 & 3,00 & 3,12 & 3,29 & 3,47 & 3,74 & 4,03 & 4,15 & 4,29 \\
\hline Ізраїль & 93 & 4,19 & 13 & 3,90 & 3,88 & 4,04 & 4,13 & 4,41 & 4,33 & 4,12 & 3,93 & 4,01 & 4,13 & 4,09 & 4,11 \\
\hline $\begin{array}{l}\text { Сполучені } \\
\text { Штати }\end{array}$ & 2,62 & 2,64 & 2,55 & 2,55 & 2,49 & 2,51 & 2,55 & 2,63 & 2,77 & 2,82 & 2,74 & 2,76 & 2,70 & 2,74 & .. \\
\hline ОЕСР - Всь & 14 & 2,18 & 15 & 2,15 & 2,13 & 2,16 & 2,19 & 2,22 & 2,29 &, 34 & 2,30 & 2,33 &, 34 &, 37 & 2,38 \\
\hline $\begin{array}{l}\text { Чеська } \\
\text { Республіка }\end{array}$ & 1,12 & 1,11 & 1,10 & 1,15 & 1,15 & 1,17 & 1,23 & 1,31 & 1,24 & 1,30 & 1,34 & 1,56 & 1,79 & 1,91 & 2,00 \\
\hline $\begin{array}{l}\text { Європейськ } \\
\text { Союз (28 кр }\end{array}$ & 1,68 & 1,70 & 1,71 & 1,70 & 1,67 & 1,67 & 1,69 & 1,70 & 1,77 & 1,84 & 1,84 & 1,88 & 1,92 & 1,93 & 1,95 \\
\hline Росія & 05 & 1,18 & 1,25 & 1,29 & 1,15 & 1,07 & 1,07 & 1,12 & 1,04 & 1,25 & 1,13 & 1,09 & 1,13 & 1,13 & 1,19 \\
\hline Польща & 0,64 & 0,62 & 0,56 & 0,54 & 0,56 & 0,57 & 0,55 & 0,56 & 0,60 & 0,67 & 0,72 & 0,75 & 0,88 & 0,87 & 0,94 \\
\hline Україна & 1,16 & 1,11 & 1,11 & 1,24 & 1,19 & 1,09 & 0,98 & 0,93 & 0,90 & 0,95 & 0,90 & 0,79 & 0,80 & 0,80 & 0,69 \\
\hline
\end{tabular}

* Укладено на основі даних [27; 28]

Якщо поглянути на зміну питомої ваги НДТР у ВВП України в 2000-2014 роках, очевидною стає тенденція до зменшення важливості витрат на НДТР. У 2000 році рівень фінансування дослідження був близьким до рівня країн ЄЄ і вищим окремих країн Європи та Росії. Якщо у 2000 році частка НДТР у ВВП становила $1,2 \%$, то у 2014 році вона стала майже вдвічі меншою - 0,69\%, опустившись нижче навіть показника Росії. Ці показники в порівнянні 3 країнами ОЕСР є малими, а від лідерів науково-технічних розробок Україна відстає колосально. Фінансування науки вже впало нижче критичного рівня, а збереження спадної тенденції може в майбутньому негативно відобразитися на економічному зростанні. Важливою $є$ і специфіка фінансування науки в Україні.

На жаль, в Україні склалась така ситуація, що вітчизняні підприємці не усвідомлюють необхідності інвестування власні кошти в дослідження і розробки та їх комерціалізацію. Починаючи із початку 2000-х років відбувалося скорочення випуску інноваційної продукції та іiї реалізації (Рис. 1).

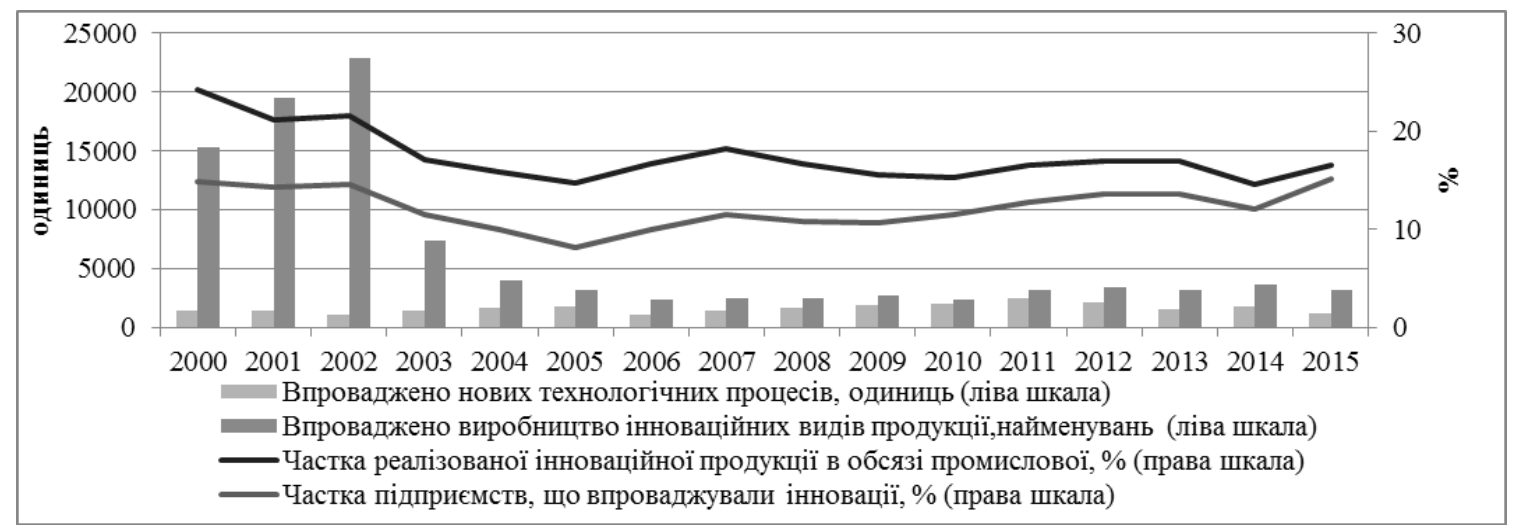

Рис. 1. Впровадження інновацій на промислових підприємствах*

* Укладено на основі даних [28]

Низьким залишається рівень впровадження технологічних інновацій у виробництві. Загалом же частка промислових підприємств, що впроваджують інновації впродовж аналізованого періоду, досягла рівня 15\% лише у 2015 році.
Дуже часто до цієї категорії підприємств належать ті, в яких присутні іноземні інвестиції. Наведені дані свідчать про те, що держава повинна створювати інститути, здатні впливати на інноваційні процеси, виступати їх ініціатором, 
стимулювати підприємства вкладати кошти в наукову сферу

Одним із ключових індикаторів, що відображає ефективність витрат праці у виробництві та сфері послуг є продуктивність праці. Одночасно це індикатор ефективності капіталістичної системи країни. Показником, що дозволяє здійс- нювати порівняння продуктивності праці різних країн вважається ВВП (за паритетом купівельної спроможності) на одного зайнятого. Україна, на жаль, значно програє за рівнем продуктивності праці як економічно розвинутим країнам, так i країнам пострадянського простору (Табл.3).

Таблиця 3

Рівень продуктивності праці в Україні та окремих країнах світу, тис.дол.США/особу [29]

\begin{tabular}{|c|c|c|c|c|c|c|c|c|c|}
\hline Країна & 1991 & 1992 & 1993 & 1994 & 1995 & 2000 & 2005 & 2010 & 2014 \\
\hline Макао, Китай (Лідер 2014 р.) & 89,59 & 97,70 & 100,27 & 103,95 & 103,61 & 85,72 & 122,82 & 163,40 & 231,32 \\
\hline Сполучені Штати & 75,72 & 78,02 & 79,00 & 80,17 & 80,83 & 91,08 & 100,62 & 106,15 & 109,31 \\
\hline Франція & 75,73 & 77,18 & 77,20 & 79,80 & 80,21 & 87,20 & 88,29 & 88,32 & 89,70 \\
\hline Німеччина & 67,04 & 69,25 & 69,50 & 71,58 & 72,33 & 77,95 & 81,51 & 81,87 & 84,05 \\
\hline Японія & 59,85 & 59,55 & 59,44 & 59,88 & 60,97 & 64,02 & 68,47 & 69,83 & 72,52 \\
\hline Словенія & 41,57 & 38,96 & 41,77 & 39,49 & 39,92 & 49,20 & 55,37 & 59,11 & 61,02 \\
\hline Угорщина & 39,19 & 36,94 & 39,04 & 40,82 & 41,83 & 46,34 & 56,09 & 57,45 & 56,30 \\
\hline Чеська Республіка & 34,28 & 34,16 & 34,22 & 34,87 & 36,80 & 42,33 & 51,25 & 56,92 & 55,94 \\
\hline Литва & 34,55 & 25,71 & 22,54 & 21,79 & 22,76 & 29,64 & 42,99 & 51,19 & 54,30 \\
\hline Польща & 22,07 & 23,31 & 24,42 & 26,11 & 27,92 & 37,61 & 44,28 & 48,87 & 53,74 \\
\hline Естонія & 27,58 & 21,43 & 19,83 & 20,58 & 22,89 & 35,15 & 46,48 & 50,44 & 53,12 \\
\hline Латвія & 26,01 & 18,21 & 17,94 & 18,73 & 19,55 & 29,08 & 40,43 & 45,43 & 48,65 \\
\hline Російська Федерація & 40,86 & 32,75 & 30,98 & 28,64 & 27,80 & 29,67 & 37,05 & 43,40 & 46,90 \\
\hline Білорусь & 16,58 & 15,18 & 14,22 & 12,71 & 11,55 & 16,46 & 24,37 & 35,71 & 39,15 \\
\hline Азербайджан & 21,26 & 16,50 & 12,39 & 9,71 & 8,34 & 11,35 & 17,92 & 33,73 & 34,89 \\
\hline Китай & 2,92 & 3,12 & 3,52 & 3,96 & 4,44 & 6,50 & 9,87 & 16,37 & 21,63 \\
\hline Парагвай & 15,14 & 14,69 & 15,26 & 15,45 & 15,53 & 15,30 & 14,14 & 16,01 & 17,44 \\
\hline Украӥна & 21,18 & 19,38 & 16,92 & 12,85 & 11,19 & 11,40 & 15,82 & 16,88 & 17,16 \\
\hline Грузія & 13,24 & 7,24 & 5,19 & 4,73 & 5,00 & 6,89 & 10,29 & 13,64 & 16,29 \\
\hline Індія & 4,91 & 5,06 & 5,18 & 5,36 & 5,68 & 6,98 & 8,45 & 12,42 & 14,68 \\
\hline $\begin{array}{l}\text { Центральноафриканська } \\
\text { Республіка } \\
\text { (Останнє місце } 2014 \text { р.) }\end{array}$ & 1,84 & 1,68 & 1,64 & 1,67 & 1,75 & 1,67 & 1,67 & 2,07 & 1,31 \\
\hline
\end{tabular}

Після здобуття незалежності рівень продуктивності праці в Україні був близький до постсоціалістичних країн, в тому числі центральної і східної Європи. Однак до 2014 р. він знизився у 1,23 рази і зараз знаходиться приблизно на рівні Парагваю. Найбільше падіння відбулося у 1992-1993 роках, а стійкої тенденції до зростання вироблено не було. Такий стан справ спричинений недоліками інституційного забезпечення економічних процесів на ринку праці. До них приєднуються причини організаційно-економічного характеру, серед яких можна виділити наступні найбільш суттєві:

- рівень оплати праці. Так у 2014 році валова середньомісячна заробітна плата становила 292,3 дол. США. Для порівняння у США рівень оплати праці більший у 16,4 рази, у Франції у 13,6 разів, в Угорщині в - 3,5 разів у Латвії у 3,1 рази [29];

- критичний стан основних засобів. Так, ступінь зносу основних засобів у 2000 році складав 43,7\%, а у 2015 році - 60,1\% (State Statistics Service of Ukraine) [28];

- значний рівень тінізації економіки, який за офіційними даними Міністерства економічного розвитку i торгівлі України складав на початку 2015 року 47\% від обсягу офіційного ВВП [31];

- низька інноваційна спроможність економіки.

Однак бар'єрами економічного росту $є$ i неефективна організація праці, особливо на держаних підприємствах, i неефективне використання людського капіталу, і відсутність реальної реструктуризації капіталу, і відсутність інституту конкуренції.

Після завершення приватизації державний сектор перестав відігравати стратегічну роль у розвитку економіки України. Більше того, незважаючи на всі недоліки української моделі приватизації, саме приватний сектор, будучи більш ефективним порівняно 3 державним, 
забезпечив поступовий вихід України з кризи у кінці 90-х років. Проблема ж монополії залишилася: замість монополії державних підприємств та «червоних директорів» сформувалася монополія республіканських, обласних та районних «олігархів». Для багатьох галузей, секторів економіки, груп підприємств монополістичний статус від державного власника перейшов до приватного. Відбулося зрощення політичної влади та бізнесу, що

створило специфічну «соціалістично-феодальну» бюджетно-роздаткову форму монополії. А внаслідок недолугості мотиваційної бази згаданих трьох специфічно сформованих українських політико-економічних інститутів: інститут антимонопольного регулятора, інститут приватної власності, інститут ведення бізнесу (підприємництва) впродовж останніх років навіть остерігається посилення монополістичних тенденцій в економіці (Табл.4).

Таблиця 4

\section{Структурні передумови конкуренції в Україні (частки ринків з різними структурними} передумовами конкуренції у загальному обсязі реалізації продукції), \% [32]

\begin{tabular}{|l|l|l|l|l|l|l|l|}
\hline \multicolumn{1}{|c|}{ Тип ринку } & $\mathbf{2 0 0 1}$ & $\mathbf{2 0 0 4}$ & $\mathbf{2 0 0 7}$ & $\mathbf{2 0 1 0}$ & $\mathbf{2 0 1 3}$ & $\mathbf{2 0 1 4}$ & $\mathbf{2 0 1 5}$ \\
\hline Ринки 3 конкурентною структурою & 53,9 & 54,3 & 53,1 & 43,8 & 45,7 & 47,5 & 42,7 \\
\hline $\begin{array}{l}\text { Олігопольні ринки (частка 5 трьох найбільших } \\
\text { підприємств більше 50 \%) }\end{array}$ & 11,6 & 15,3 & 14,4 & 12,5 & 15,9 & 15,4 & 16,7 \\
\hline $\begin{array}{l}\text { Ринки 3 ознаками одноосібного домінування(частка } \\
\text { найбільшого підприємства більше 35 \%) }\end{array}$ & 22,7 & 19,9 & 25,8 & 30,7 & 25,4 & 25,4 & 30,8 \\
\hline $\begin{array}{l}\text { Монополізовані ринки (частка найбільшого } \\
\text { підприємства більше 90 \%) }\end{array}$ & 11,8 & 10,5 & 6,7 & 8,5 & 11,8 & 11,8 & 9,8 \\
\hline
\end{tabular}

У сегменті великого бізнесу традиційно, досить олігопольно конкурентними для України $\epsilon$ тільки ринки продукції сільського господарства та (частково) металургійної продукції. I навпаки високий рівень монополізації спостерігається у електроенергетиці (високовольтні мережі, центральне диспетчерське управління, обленерго), газопостачанні, зв'язку (телефонні мережі, послуги пошти), транспорті (залізниці, авіаперевезення, порти, трубопроводи). Згідно даних Антимонопольного комітету України серед порушень законодавства про захист економічної конкуренції традиційно найбільшу частку (48\% у 2015 р.) займає зловживання домінуючим (монопольним) становищем, в першу чергу зловживання цінового характеру.

Таким чином, фактичні дані свідчать, що інститут конкуренції не сформувався ні на основоположних для соціально-економічного розвитку України ринках попиту, ні на технологічно-сучасних ринках пропозиції. Це поступово приводить до колапсу внутрішнього національного ринку в цілому.

Висновки i перспективи подальших досліджень. Внаслідок формування юридично та морально недолугої системи інститутів приватної власності відбулося неприродне «антикапіталістичне» роз'єднання рівня вигід та відповідальності за право використання приватної власності, право розпоряджатися власністю, право користуватися власністю. В результаті в Україні так i не утворилися самоорганізаційні джерела росту ефективності національного бізнесу. Діючі в Україні інститути підприємництва не стали самоорганізаційними джерелами формування механізмів ефективної конкуренції. Українські інститути підприємництва (формальний і неформальний) не стали передумовою продукування ефективної ринкової інформації та стимулювання економічного росту до нових все вищих рівнів спонтанної ринкової рівноваги.

Інститут демонополізації та інститут приватизації (у формі ваучерної приватизації) не створили можливість масового доступу до ресурсів для потенційно підприємливих людей, що $є$ необхідним для формування ефективного ринку. Цим провалено вирішення основного завдання якісного роздержавлення 3 метою формування ринку ефективних капіталів. Цим самим загальмовано та спотворено формування суспільно значимого інституту приватної власності у дусі сучасного соціально-орієнтованого «народного капіталізму». Використання «антимонопольних» інституційних інструментів, необхідних для функціонування ринку, усе ще відбувається за принципом «вибіркового правосуддя», що фундаментально гальмує розвиток національного бізнесу.

Внаслідок запровадження ерзац-ринкових інститутів відбулося формування специфічної економіко-політичної касти ерзац «феодалбуржуазії». Відсутність реальних механізмів банкрутства у випадках втрати ефективності бізнесу зумовлює замикання на себе пануючої касти, руйнуванню основ конкуренції, антисоціалізацію бізнесменів, деградацію соціальної відповідальності бізнесу. Відбувається повна деградація механізмів соціально-економічних ліфтів для молодого покоління в межах країни. 
Це призводить до відтоку людського капіталу в розвинені капіталістичні країни. В результаті сформувалася негативна динаміка розвитку національного бізнесу: встановився самоорганізаційний режим циклічного «повернення в минуле» економіки. Рух інверснотрансформаційної економіки України відбувається по фазам циклу: від феодального капіталізму до ерзац-капіталізму і знову назад до феодального капіталізму. Запровадженні формули «субсидійний капіталізм» 20152017 pp. - це новий виток відтворення феодалкапіталізму. В цьому витку для соціуму неефективний керівник «одержавленої» компанії може мати одночасно i феодальний статус (державний броньований мерседес), i капіталістичний статус (сто мінімальних зарплат). В результаті таких часто повторюваних інституційних колізій якість національного капіталу (виробничого,

фінансового, інвестиційного, людського, інтелектуального, соціального) не може стати визначальною для позитивної динаміки національного бізнесу.

Загалом застосування логіки «ринкового фундаменталізму» та ліберальної парадигми шкідливе для економіки України. Відтак перспективи подальших досліджень лежать в площині подальшого виявлення бар'єрів розширеного відтворення національної економіки України. В першу чергу це стосується бар'єрів розвитку національного бізнесу та конкуренції інституційного характеру. Водночас необхідно i далі «широким фронтом» дослідників розробляти адекватні новим умовам викликів глобалізації економічні механізми та стратегічні моделі подолання трансформаційної кризи.

\section{ПЕРЕЛІК ВИКОРИСТАНИХ ДЖЕРЕЛ}

1. Войтович Р.В. Вплив глобалізації на розвиток сучасного світу [Електронний ресурс] / Р.В.Войтович. Режим доступу: http://www.vidkryti-ochi.org.ua/2013/06/blog-post.html

2. North D. C. Institutions, institutional change and economic performance. - Cambridge: Cambridge University Press, 1990. $-153 \mathrm{p}$.

3. Luhmann N. Soziologishe Aufkelrung. Aufsitze zur Theorie sozialer Systeme. - Opladen: Westdt. Verl., 1991

4. Kornai J. (1998). The System Paradigm / J. Kornai // William Davidson Institute Working Papers Series. 1998. - № 278.

5. Клейнер Г. Системная парадигма и теория предприятия / Г.Клейнер //Вопросы экономики. - 2002. - №. 10. - С. $47-69$.

6. Клейнер Г. Б. Эволюция институциональных систем. М.: Издательство «Наука», 2004.- 240 с.

7. Freedom House. Nations in Transit 2003 [Електронний ресурс]. - Режим доступу: https://freedomhouse.org/report/nations-transit/nations-transit-2003

8. Freedom House. Nations in Transit 2006 [Електронний ресурс]. - Режим доступу: https://freedomhouse.org/report/nations-transit/nations-transit-2006

9. Freedom House. Nations in Transit 2008 [Електронний ресурс]. - Режим доступу: https://freedomhouse.org/report/nations-transit/nations-transit-2008

10. Freedom House. Nations in Transit 2012 [Електронний ресурс]. - Режим доступу: https://freedomhouse.org/report/nations-transit/nations-transit-2012

11. Freedom House. Nations in Transit 2015 [Електронний ресурс]. - Режим доступу: https://freedomhouse.org/report/nations-transit/nations-transit-2015

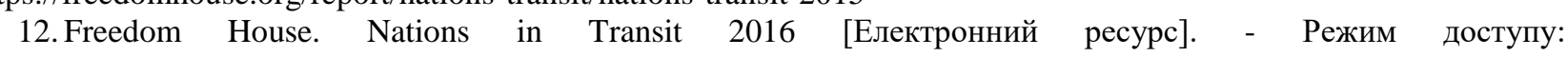
https://freedomhouse.org/report/nations-transit/nations-transit-2016

13. Heritage Foundation. Index of Economic freedom. - 2017 [Електронний ресурс]. - Режим доступу: http://www.heritage.org/index/

14. The Bertelsmann Stiftung's Transformation Index [Електронний ресурс] - Режим доступу: https://www.btiproject.org/en/reports/

15. The World Justice Project. Rule of Law Index 2012-2013 [Електронний ресурс] . - Режим доступу: http://worldjusticeproject.org/sites/default/files/WJP_Index_Report_2012.pdf

16. The World Justice Project. Rule of Law Index 2015 [Електронний ресурс] - - Режим доступу: http://worldjusticeproject.org/sites/default/files/roli_2015_0.pdf

17. The World Justice Project. Rule of Law Index 2016 [Електронний ресурс] . - Режим доступу: http://data.worldjusticeproject.org/\#groups/UKR

18. World Bank. Doing Business 2009 [Електронний pecypc] . Washington: World Bank.- Режим доступу: http://www.doingbusiness.org/ /media/WBG/DoingBusiness/Documents/Annual-Reports/English/DB09-

FullReport.pdf

19. World Bank. Doing Business 2012: Doing Business in a More Transparent World. Електронний ресурс]. Washington: World Bank. - Режим доступу: http://www. doingbusiness.org/ /media/FPDKM/Doing\%20Business/Documents/Annual-Reports/English/DB12-FullReport.pdf 
20.World Bank. Doing Business 2015: Going Beyond Efficiency. Електронний pecypc] . Washington: World Bank. Режим доступу: http://www.doingbusiness.org/ /media/GIAWB/Doing\%20Business/Documents/Annual - Reports/English/DB15Full-Report.pdf

21. World economic forum. Global Competitiveness Report 2006-2007. [Електронний ресурс]. - Режим доступу: http://www3.weforum.org/docs/WEF_GlobalCompetitivenessReport_2006-07.pdf

22. World economic forum. Global Competitiveness Report 2011-2012. [Електронний ресурс]. - Режим доступу: http://www3.weforum.org/docs/WEF_GCR_Report_2011-12.pdf

23. World economic forum. Global Competitiveness Report 2015-2016. [Електронний ресурс]. - Режим доступу: http://www3.weforum.org/docs/gcr/2015-2016/Global_Competitiveness_Report_2015-2016.pdf

24. World economic forum. Global Competitiveness Index 2016-2017 edition. [Електронний ресурс] . - Режим доступу: http://reports.weforum.org/global-competitiveness-index/country-profiles/\#еconomy=UKR

25. The Worldwide Governance Indicators project. The worldwide governance indicators. [Електронний ресурс] . - Режим доступу: http://info.worldbank.org/governance/wgi/\#reports

26. Transparency International Ukraine. Дослідження. Національна система доброчесності Україна-2015. [Електронний ресурс]. - Режим доступу: https://ti-ukraine.org/research/doslidzhennya-natsionalna-systemadobrochesnosti-ukrajina-2015/

27. Organisation for Economic Co-operation and Development.Stat. Main science and technology indicators. $2017 . \quad$ [Електронний pecypc].

http://stats.oecd.org/viewhtml.aspx?datasetcode=MSTI_PUB\&lang=en

Режим доступу:

28. State Statistics Service of Ukraine. Retrieved from http://www.ukrstat.gov.ua/

29. The World Bank. GDP per person employed [Електронний pecypc] . - Режим доступу: http://data.worldbank.org/indicator/SL.GDP.PCAP.EM.KD?end=2014\&name_desc=false\&start=1991

30. United Nations Economic Commission for Europe. Gross average monthly wages by country and year. [Електронний ресурс] . - Режим доступу: http://w3.unece.org/PXWeb2015/pxweb/en/STAT/STAT_20-ME_3MELF/60_en_MECCWagesY_r.px/table/tableViewLayout1/?rxid=15f8644e-3f4d-4f05-b8fd-a1c585f610af

31. Міністерство економічного розвитку і торгівлі України. Тенденції тіньової економіки в Україні 1 квартал 2015 року [Електронний ресурс]. - Режим доступу: http://www.me.gov.ua/Documents/Download?id=da2436068d4b-49f5-9fa4-34994d5db4d2

32. Антимонопольний комітет України. Звіт Антимонопольного комітету України за 2015 рік [Електронний pecypc]. - Режим доступу: http://www.amc.gov.ua/amku/doccatalog/document?id=122547\&schema=main

\section{REFERENSES}

1. Voitovych, R. V. (2013, 5 June) Vplyv hlobalizatsii na rozvytok suchasnoho svitu [Impact of globalization on the development of the modern world]. Vidkryti ochi (in Ukrainin). Retrieved from http://www.vidkrytiochi.org.ua/2013/06/blog-post.html

2. North, D. (1990). Institutions, institutional change and economic performance. Cambridge: Cambridge University. Press Verl.

3. Luhmann, N. (1991) Soziologishe Aufkelrung. Aufsitze zur Theorie sozialer Systeme. Opladen: Westdt.

4. Kornai, J. (1998). The System Paradigm. William Davidson Institute Working Papers Series 278. William Devidson Institute at the University of Michigan.

5. Kleiner, H. (2002). Systemnaia paradyhma y teoryia predpryiatyia [System paradigm and enterprise theory] . Voprosy ekonomiki, 10, 47-69. [in Russian].

6. Kleiner, H. (2004). Evoliutsyia instytutsyonalnykh sistem [Evolution of institutional systems]. Moskow: Yzdatelstvo "Nauka".[in Russian].

7. Freedom House. (2003). Nations in Transit 2003. Retrieved from https://freedomhouse.org/report/nationstransit/nations-transit-2003

8. Freedom House. (2006). Nations in Transit 2006. Retrieved from https://freedomhouse.org/report/nationstransit/nations-transit-2006

9. Freedom House. (2008). Nations in Transit 2008. Retrieved from https://freedomhouse.org/report/nationstransit/nations-transit-2008

10. Freedom House. (2012). Nations in Transit 2012. Retrieved from https://freedomhouse.org/report/nationstransit/nations-transit-2012

11. Freedom House. (2015). Nations in Transit 2015. Retrieved from https://freedomhouse.org/report/nationstransit/nations-transit-2015

12. Freedom House. (2016). Nations in Transit 2016. Retrieved from https://freedomhouse.org/report/nationstransit/nations-transit-2016

13. Heritage Foundation. (2017). Index of Economic freedom. Retrieved from http://www.heritage.org/index/

14. The Bertelsmann Stiftung's Transformation Index. Retrieved from https://www.bti-project.org/en/reports/ 
15. The World Justice Project. (2013). Rule of Law Index 2012-2013. Retrieved from http://worldjusticeproject.org/sites/default/files/WJP_Index_Report_2012.pdf

16. The World Justice Project. (2015). Rule of Law Index 2015. Retrieved from http://worldjusticeproject.org/sites/default/files/roli_2015_0.pdf

17. The World Justice Project. (2016). Rule of Law Index 2016. Retrieved from http://data.worldjusticeproject.org/\#groups/UKR

18. World Bank. (2008). Doing Business 2009. Washington: World Bank. Retrieved from http://www.doingbusiness.org/ /media/WBG/DoingBusiness/Documents/Annual-Reports/English/DB09-

FullReport.pdf

19. World Bank. (2013). Doing Business 2012: Doing Business in a More Transparent World. Washington: World Bank. Retrieved from http://www. doingbusiness.org/ /media/FPDKM/Doing\%20Business/Documents/AnnualReports/English/DB12-FullReport.pdf

20. World Bank. (2016). Doing Business 2015: Going Beyond Efficiency. Washington: World Bank. Retrieved from http://www.doingbusiness.org/ /media/GIAWB/Doing\%20Business/Documents/Annual- Reports/English/DB15Full-Report.pdf

21. World economic forum. (2007). Global Competitiveness Report 2006-2007. Retrieved from http://www3.weforum.org/docs/WEF_GlobalCompetitivenessReport_2006-07.pdf

22. World economic forum. (2012). Global Competitiveness Report 2011-2012. Retrieved from http://www3.weforum.org/docs/WEF_GCR_Report_2011-12.pdf

23. World economic forum. (2016). Global Competitiveness Report 2015-2016. Retrieved from http://www3.weforum.org/docs/gcr/2015-2016/Global_Competitiveness_Report_2015-2016.pdf

24. World economic forum. (2017). Global Competitiveness Index 2016-2017 edition. Retrieved from http://reports.weforum.org/global-competitiveness-index/country-profiles/\#economy=UKR

25. The Worldwide Governance Indicators project (2017). The worldwide governance indicators. Retrieved from http://info.worldbank.org/governance/wgi/\#reports

26. Transparency International Ukraine. (2016). Research. National integrity system assessment Ukraine-2015. Retrieved from https://ti-ukraine.org/research/doslidzhennya-natsionalna-systema-dobrochesnosti-ukrajina-2015/

27. Organisation for Economic Co-operation and Development.Stat. (2017). Main science and technology indicators. Retrieved from http://stats.oecd.org/viewhtml.aspx?datasetcode=MSTI_PUB\&lang=en

28. State Statistics Service of Ukraine. Retrieved from http://www.ukrstat.gov.ua/

29. The World Bank. (2017). GDP per person employed . Retrieved from http://data.worldbank.org/indicator/SL.GDP.PCAP.EM.KD?end=2014\&name_desc=false\&start=1991

30. United Nations Economic Commission for Europe. (2017). Gross average monthly wages by country and year. from http://w3.unece.org/PXWeb2015/pxweb/en/STAT/STAT_20-ME_3MELF/60_en_MECCWagesY_r.px/table/tableViewLayout1/?rxid=15f8644e-3f4d-4f05-b8fd-a1c585f610af

31. Ministry of Economic Development and Trade of Ukraine. (2015). Tendentsii tinovoi ekonomiky v Ukraini I kvartal 2015 roku [The trends of the shadow economy in Ukraine in the first quarter of 2015]. Retrieved from http://www.me.gov.ua/Documents/Download?id=da243606-8d4b-49f5-9fa4-34994d5db4d2

32. Antimonopoly Committee of Ukraine. (2016). Zvit Antymonopolnoho komitetu Ukrainy za 2015 rik [Report of the Antimonopoly Committee of Ukraine for 2015]. Retrieved from http://www.amc.gov.ua/amku/doccatalog/document?id=122547\&schema=main

Одержано 15.09.2017p. 